\title{
PEDAGOGICAL GRAMMAR AS THE FRAMEWORKOF TEFL RESEARCH.PART 7. NATIVE LANGUAGE SYNTAX ACQUISITION: CONCEPTUAL COMPLEXITY
}

\section{Chernovaty L.M., Doctor of Pedagogics (Kharkiv)}

The paper presents the results of the experimental data analysis in the said sphere. Basing upon a high degree of the data similarity, the author makes a conclusion that the native language (English) syntax acquisition is a rule-governed process with its specific stages. Taking into account the said data, the author also offers some assumptions concerning the content of stages in the process of tag questions, negation, passive constructions and relative clauses acquisition in English as a native language, as well as regarding the conditions of fully inverted tag questions emergence in the child's speech and the potential catalysts of this process. The paper analyses the influence of the minimal proximity principle on the correct interpretation of relative clauses and those containing passive constructions by the young children of different age groups. The author offers an assumption concerning the gradual character of the acquisition of conceptually complicated syntactic categories, in particular, about the dissimilar transfer speed of the passive construction use rule to the verbs indicating actions, on the one hand, and states - on the other. The paper lists the factors affecting the sequence and speed of the syntactic means acquisition, which include the semantic and grammatical complexity, frequency of use and perceptual salience. The author generalizes the stages of syntax acquisition, which include the acquirement of the sentence structure elements linear sequence (where the notions of 'precedence' and 'succession' are acquired); the acquisition of the rules, which do not take into account the sentence structure; the primary consolidation of sentence elements in terms of their surface features; the identification of sentence components on the basis of the minimum proximity principle; the formulation of the rule, which takes into account the sentence structure and its expansion to a small class of words; the gradual expansion of the latter rule to the entire class of words. The paper outlines the prospects of further research concerning the development of pedagogical grammar, taking into account the abovementioned conclusions.

Key words: minimal proximity principle, native language acquisition, negation, passive constructions, relative clauses, stages of acquisition, syntax acquisition, tag questions.

Черноватий Л.М. Педагогічна граматика як фреймове поняття для досліджень у галузі методики навчання іноземних мов. Частина 7. Засвосння синтаксису рідної мови: концептуальна складність. Наводяться результати аналізу даних досліджень у згаданій сфері. Виходячи 3 високого ступеня подібності таких результатів, сформульовано висновок про те, що зміст засвоєння синтаксису англійської мови як рідної базується на певних етапах. Грунтуючись на результатах аналізу, запропоновано висновки про зміст етапів засвоєння структур розділового запитання, заперечення, пасивних конструкцій та відносних речень, а також про умови появи повністю інвертованих розділових запитань у мовленні дитини та можливих каталізаторах цього процесу. Розглянуто вплив принципу мінімальної віддаленості на вірність тлумачення дітьми різного віку

(C) Chernovaty L.M., 2019 
відносних речень, а також тих, що містять пасивні конструкції. Запропоновано тезу про поступовий характер формування концептуально ускладнених синтаксичних категорій, зокрема, про різну швидкість поширення правил уживання пасивного стану на дієслова, що передають дії та стани. Сформульовано висновок про чинники, що впливають на послідовність і швидкість засвоєння синтаксичних засобів, які включають семантичну та граматичну складність, частотність і перцептуальну випуклість. Окреслено перспективи подальшого дослідження з урахуванням отриманих результатів в процесі розробки педагогічної граматики іноземної мови.

Ключові слова: відносні речення, засвоєння синтаксису, засвоєння рідної мови, етапи засвоєння, заперечення, пасивні конструкції, принцип мінімальної віддаленості, розділові запитання.

Черноватый Л.Н. Педагогическая грамматика как фреймовое понятие для исследований в области методики обучения иностранным языкам. Часть 7. Усвоение синтаксиса родного языка: концептуальная сложность. Приводятся результаты анализа данных исследований в упомянутой сфере. Исходя из высокой степени сходства таких результатов, сформулированы выводы о наличии определенных этапов процесса усвоения синтаксиса английского языка как родного. Основываясь на результатах анализа, предложены выводы о содержании этапов усвоения структур разделительного вопроса, отрицания, пассивных конструкций и относительных предложений, а также об условиях появления полностью инвертированных разделительных вопросов в речи ребенка и возможных катализаторах этого процесса. Рассмотрено влияние принципа минимальной удаленности на верность интерпретации детьми разного возраста относительных предложений и тех, которые содержат пассивные конструкции. Предложен тезис о постепенном характере формирования концептуально усложненных синтаксических категорий, в частности, о разной скорости распространения правила употребления структур страдательного залога на глаголы, обозначающие действия и состояния. Сформулирован вывод о факторах, влияющих на последовательность и скорость усвоения синтаксических средств, которые включают семантическую и грамматическую сложность, частотность и перцептуальную выпуклость. Очерчены перспективы дальнейшего исследования с учетом полученных результатов в процессе разработки педагогической грамматики иностранного языка.

Ключевые слова: относительные предложения, отрицание, пассивные конструкции, принцип минимальной удаленности, разделительные вопросы, усвоение родного языка, усвоение синтаксиса, этапы усвоения.

Introduction to the series. Numerous research in teaching foreign languages, specifically in the development of grammar competence, often seem to lack a common framework to integrate them into a single area with uniform approaches, terminology and criteria. It accounts for the current importance of the issue under consideration.

The object of this part of theseries is the comparative aspect of the native (NLA) and foreign languages acquisition (FLA) with the subject 
being the characteristics of the NLA. Its aim is to analyse the latter with the purpose of its further comparison with the FLA. This is the seventh (see, the full list in [4]) in a series of articles focusing on the Pedagogical Grammar (PG) issue [1], where the author, basing on the research data, is planning to discuss the various aspects of the problem.

As it was mentioned in the previouspapers of the series (see [4]), the development of an effective PG should be based on a sound psycholinguistic theoryof the FLA. This kind of PG has to take into consideration the specificsof the speech grammar mechanisms development in general and the foreign language grammar mechanisms in particular, especially in the spheres where the NLA and FLA features are different. In our earlier articles (see the list in [4]), we started reviewing the strategies, procedures and processes at the simple sentencestage in the NLA. Specifically, in our latest contribution [4] we analysed the syntax acquisition (yes-no- and wh-questions) in the NLA. In this paper, we are going to reviewthe acquisition of tag questions, negation, relative clauses and passive structures in the NLA. The data concerning the native language syntax acquisitionwould then be used for the comparison with the FLA in our next papers.

Syntax acquisition has many features similar to those of morphology acquisition. However, the former naturally possesses some specific features as well, probably because syntax is related to a deeper language structure as compared to morphology. In addition, the actions involved in the sentence structure build-up usually include at least several operations. As a result, they may be more complicated, especially if the said actions require the performance of both syntactic and morphological operations. For example, the use of the Present Perfect in the declarative sentence calls at least for the following operations: (1) identify the situation of communication as the one that requires the use of the Present Perfect; (2) select the subject of the sentence; (3) realize the need for an auxiliary verb; (4) select have as an auxiliary verb; (5) realize the need for the auxiliary verb agreement with the sentence subject; (6) check whether the subject is represented by a noun in the third person singular; (7a) if yes, choose the form has; (7b) if no, choose the form have; (8) realize the need for a notional verb; (9) select the notional verb; (10) realize the need for the notional verb conversion into its past participleform; (11) check whether this is a regular verb; (12a) if yes, add -edto the notional verb; (12b) if no, 
choose the appropriate form; (13) finish the utterance. As we can see, the action of generating a declarative sentence with the verb in the Present Perfect form requires at least 13 syntactic and morphological operations, which are virtually invisible in fluent speech. However, this invisibility is the result of a relatively long process of the constituent operations interiorization.

As it follows from the available research $[1 ; 2 ; 3 ; 4 ; 8 ; 10 ; 13]$, syntax acquisition starts approximately at the age of two years with the acquirement of two types of structures: $N+V+N$ (e.g.The cat ate the fish) and $N+$ be $+N$ (e.g. The baby is a boy). Naturally, in actual usage at the initial stages of acquisition, function words may be omitted, resulting in the sentences like Cat ate fish and Baby boy. The reasons for such telegraphic sentences have been discussed in our previous papers in the series (see the list in [4]).

The acquisition of the verb phrase (VP) is accompanied by broadening the range of the verb use due to the acquirement of a number of inflections, among them -ingfor the Present Continuous; sfor the third person singular in the Present Indefinite; -ed for the Past Indefinite (see the sequence of their acquisition in [3]). Simultaneously we witness the massive emergence of auxiliary verbs in the child's speech. However, as we mentioned in our previous paper [3], at this early stage they are acquired as isolated words (see [3]), which are not related to the development of any internal rule concerning their use, including their role in rendering the syntactic relations. Thus can't, won't and don't are the mere variants of not, as can, will and do are still absent in the child's speech. Therefore, their negative forms should be regarded as the words, which got into the child's lexicon because of mechanical memorization, and which are stored in the memory as inseparable units. It restricts their participation in the sentence syntactic build-up. The same restriction concerns other grammar elements (e.g. have, might, would, etc.),also acquired as isolated words, which lacked the corresponding processing, generalization and the rule formation. This stage has another restriction, which does not allow using more than one marker for the same verb. It results in the sentences likeMommy eating instead of Mommy was eating.

Acquisition of modifiers proceeds stage by stage.First, the child acquires the means to express the modifiers of place, as well as those involved in answering the questions, beginning with what and where. 
The means to express the modifiers of time, manner and cause are acquired much later. Because the same picture is observed in the interrogative structures acquisition (see [4]), we may assume the conceptual complexity of the underlying notions.

The child tries to compensate for the inferiority of his/her syntactic mechanisms by means of mechanically memorizing the whole chunks of adult speech, which s/he inserts in his/her own utterance. For example, the adult: What kind of truck is it? - The child: It's kind of truck (see other examples of the morphology acquisition in [3]).

Tag questions. The mechanisms of the tag question acquisition have been studied by a number of authors $[5 ; 6 ; 11 ; 12 ; 16 ; 17]$ on the material of several languages. Some studies [12] dealt with the disjunction operator properties and their acquisition by Englishspeaking children. Others [11] were concerned with the positive polarity in Japanese. Still others [17] focused on simple and complex disjunctions in French and Japanese, children's interpretation of disjunction in the scope of 'before' [17] and other issues. The authors generally agree that this kind of question is rather difficult and its fullfledged acquisition is completed rather late in the language development.

The tag question requires at least four operations.

(1) the pronomilization of the subject noun in the first (declarative) part of the sentence:

John likes sports,

(2) the contraction of the verb group to a single operator

(3) the reversal of the declarative polarity in the tag
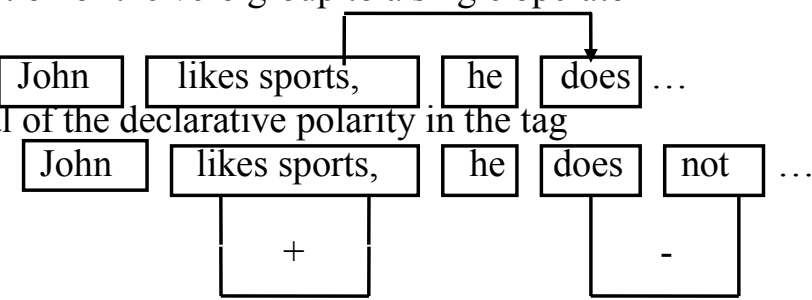

(4) the subject-operator inversion

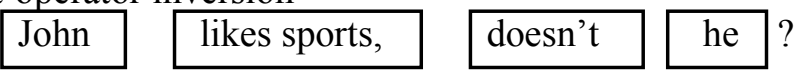

Because of its said complexity, the tag question acquisition iscompleted after the yes-no and wh-questions had been acquired. 
However, at the earlier stages of their linguistic development the children successfully perform the tag question function lexically (e.g., It's snowing, right?).

Research (see the review in [13]) suggested an assumption concerning the pre-requisites necessary for the tag question acquisition. According to this assumption, for this aim, the child has to acquire the following operations: (1) ellipse of the declarative structure: It's a book $\rightarrow$ Yes, it is; (2) negation: It's a book $\rightarrow$ It's not a book; (3) ellipse of the negation: It's a book $\rightarrow N o$, it isn't; (4) inversion: It's a book $\rightarrow$ Is it a book?; (5) negative question: It's a book $\rightarrow$ Isn't it abook?; (6) ellipse of the negative question: It's not a book $\rightarrow$ Isn't it? It is assumed that we may expect the fully inverted tag questions in the child's speech only after the acquisition of all those operations. The increase in the amount of tag questions in the child's input may serve as a catalyst of this process.

Acquisition of negation. According to the available research $[7 ; 9$; $13 ; 14 ; 15]$, the child goes through the following stages in this process.

At stage 1 the child's sentences are based on the model $S t \rightarrow$ $(n o / n o t)+$ the nucleus of the sentence $+($ no/not $)$, where $S t-$ sentence (e.g. No wipe finger; Wear mitten no). Here no/not function as the words of P1 or P2 classes in the pivot grammar(see the review in [13]).

The indicators of stage 2 are the structures based on the model $S t$ $\rightarrow$ Nom + Aux neg + predicate / notional verb, where St - sentence, Nom - noun or pronoun in the nominative case, Aux neg - auxiliary negative element, which may be expressed by means of no, not or don't (e.g. He not little; He no bite you; He don't little).

At stage 3 the child uses not correctly. Though formally not is a grammar morpheme, we review the stages of its acquisition here for two reasons. First, because it alternates its positions in the sentence at the different stages, behaving like a syntactic element, and second, because the stages of its acquisition, as well as those of the interrogative structures, would be later used in the analysis of 'interim structures'.

Acquisition of other conceptually complicated structures. In addition to tag questions, there is a range of other structures whose late acquisition may be related to their complexity. Passive structures and relative clauses are among them.

Conceptual complexity is believed to be the main reason for the late 
acquisition of passive structures. According to the available research (see the review in [13]), children perceive the sequence "noun - verb noun" as equivalent to the sequence "agent - action - patient", which results in the misinterpretation of passive sentences. It is thought that it happens because of the minimum proximity principle effect, which makes the child believe that the noun, which is the closest one to the predicate, is the agent. Consequently, the child misinterprets the sentences of the following types: (1) The cat was kissed by the rabbit (the child perceives it as The cat kissed the rabbit); (2) The man who saw the deer ate the pie (= The deer ate the pie); (3) John is easy to see (= It's easy for John to see); (4) John promised Mary to water the garden (= Mary watered the garden) (see the review in [13]). The minimum proximity principle effect may be also illustrated on the material of relative clauses. For example, the sentence (5) The cat chased the mouse that frightened the girl is easily understood even by two-year-old children, while the sentence (6) The cat chased the mouse that the girl frightened causes problems, and the sentence (7) The girl that the mouse frightened chased the cat is misinterpreted practically by all children between two and four years of age (see the review in [13]). The comparison of sentences 5-7 shows that the problems in their perception are caused by the minimum proximity principle effect. Sentence 7 contains two instances when the noun closest to the predicate is not the agent, sentence 6 - one instance, while in sentence 5 this principle is not violated, and that is why it is the easiest one for comprehension and acquisition.

Like many other phenomena, passive and relative clauses are not acquired en masse as a category. The passive, for example, is assimilated in the course of several years, gradually expanding the effect of its rule of usage to the new and new classes of words. As far as the passive is concerned, all verbs may be subdivided into two broad categories - 'actions' and 'states'. According to the available data, 'actions' in general are acquired first, while 'states' follow them. Moreover, any 'actions' are acquired better than any 'states' (see the review in [13]). It may be regarded as another proof in favour of the assumption that the sequence of acquisition depends on the conceptual complexity of the object of acquisition.

As a kind of generalization, we may conclude that the sequence and speed of syntax acquisition depends on practically the same factors 
that were observed in relation to morphology: semantic and grammar complexity, frequency and, to some degree, perceptual salience (the latter is probably true only concerning yes-no questions, and only at the stage where they are acquired according to the lexical principle).Basing upon the analysis given above, it may be assumed that the syntax acquisition in general has the following stages.

1. The acquisition of the linear sequence of the sentence structure elements, where the notions of 'precedence' and 'succession' are acquired.

2. The acquisition of the rules, which do not take into account the sentence structure. The primary consolidation of sentence elements in terms of their surface features. Identification of sentence components on the basis of the minimum proximity principle. Errors in the evaluation of the sentences like Which balls are the boy throwing? and Which ball is the boys throwing?

3. The formulation of the rule, which takes into account the sentence structure and its expansion to a small class of words.

4. The gradual expansion of the rule, which takes into account the sentence structure to the entire class of words.

Taking into consideration the practical invariability of the stages in the native language syntax acquisition, the existence of similar features in the foreign language syntax acquisition could be regarded as a serious proof of the two processes fundamental similarity, which is the prospect of our further research.

\section{LITERATURE}

1. Черноватый Л.Н. Основы теории педагогической грамматики иностранного языка: дис. ... д-ра пед. наук: 13.00 .02 / Харьковский нац. ун-т им. В.Н. Каразина. Харьков, 1999. 453 с.

2. Brown R. A First Language: The Early Stages. Cambridge, Mass.: Harvard Univ. Press, 1973. 430 p.

3. Chernovaty L.M. Pedagogical grammar as the framework of research in teaching foreign languages. Part 5. Native language morphology acquisition at the simple sentence stage. Викладання мов у вищих навчальних закладах освіти на сучасному етапі. Міжпредметні зв'язки. Х.: ХНУ ім. В.Н. Каразіна, 2018. Вип. 33. С. 118-126.

4. Chernovaty L.M. Pedagogical grammar as the framework of research in teaching foreign languages. Part 6. Native language syntax acquisition: yesno- and why-questions. Викладання мов у вищих навчальних закладах 
освіти на сучасному етапі. Міжпредметні зв'язки. Х.: ХНУ ім. В.Н. Каразіна, 2019. Вип. 34. С. 246-257.

5. Chierchia G., Crain S., Guasti M., Gualmini A., Meroni L. The acquisition of disjunction: Evidence for a grammatical view of scalar implicatures. Proceedings of the 25th Boston University Conference of Language Development. Somerville, MA: Cascadilla Press, 2000. P. 157-168.

6. Crain S., Goro T., Thornton R. Language Acquisition is Language Change. Journal of Psycholinguistic Research. 2006. Vol. 35. No 1. P. 31-49. DOI: 10.1007/s10936-005-9002-7.

7. Crain S., Gardner A., Gualmini A., Rabbin B. Children's command of negation. Proceedings of the third Tokyo Conference on Psycholinguistics / ed. Yukio Otsu.Tokyo: Hituzi Publishing Company, 2002. P. 71-95.

8. de Villiers J., de Villiers P. Language Acquisition. Cambridge, Mass.: Harvard Univ. Press, 1978. 312 p.

9. Dimroth Ch. The acquisition of negation. The expression of negation / ed. Horn L.R. Berlin: De Gruyter Mouton. 2010. P. 39-73. DOI: 10.1515/9783110219302.39.

10. Erreich A., Valian V., Winzemer J. Aspects of a theory of language acquisition. Journal of Child Language. 1980. No 2. P. 157-179.

11. Goro T., Akiba S. The acquisition of disjunction and positive polarity in Japanese. Proceedings of WCCFL 23 / eds. G. Garding, M. Tsujimura. Somerville, MA: Cascadilla Press, 2004. P. 101-114.

12. Gualmini A., Crain S., Meroni L. Acquisition of disjunction in conditional sentences. Proceedings of the 24th Boston University Conference of Language Development. Somerville, MA: Cascadilla Press, 2000. P. 367378.

13. Ingram D. First Language Acquisition. Cambridge: Cambridge Univ. Press, 1992. $572 \mathrm{p}$.

14. Islam Y. Phases in L1 Acquisition of Negation: A Comparative Study of Cairene Arabic and English. SKASE Journal of Theoretical Linguistics. 2015. Vol. 12. No 4. P. 17-27.

15. Kusmanto J., Pulungan A. The acquisition of English negation "no" and "not": evidences from an Indonesian child in non-native parents bilingual program. K@ta: a Biannual Publication on the Study of Language and Literature. 2003. Vol. 5. No 1. P. 41-48.

16. Notley A., Zhou P., Jensen B., Crain S. Children's interpretation of disjunction in the scope of "before": A comparison of English and Mandarin. Journal of Child Language. 2012. Vol. 39. No 3. P. 482-522.

17. Tieu L., Yatsushiro K., Cremers A., Romoli J., Sauerland U., Chemla E. On the Role of Alternatives in the Acquisition of Simple and Complex Disjunctions in French and Japanese. Journal of Semantics. 2017. Vol. 34. No. 1. P. 127-152. DOI: https://doi.org/10.1093/jos/ffw010. 


\section{REFERENCES}

Brown, R. (1973). A First Language: The Early Stages. Cambridge, Mass.: Harvard Univ. Press [in English].

Chernovaty, L. (1999). Osnovy teorii pedagogicheskoi grammatiki inostrannogo yazyka [The Basics of the Foreign Language Pedagogical Grammar Theory]. Doctor of Sciences thesis. Kharkiv: V.N. Karazin Kharkiv National University [in Russian].

Chernovaty, L.M. (2018). Pedagogical grammar as the framework of research in teaching foreign languages. Part 5. Native language morphology acquisition at the simple sentence stage. Vykladannia mov u vyshchykh navchalnykh zakladakh osvity na suchasnomu etapi. Mizhpredmetni zviazky [Teaching Languages at Higher Institutions], 33, pp. 118-126 [in English].

Chernovaty, L.M. (2018). Pedagogical grammar as the framework of research in teaching foreign languages. Part 6 . Native language syntax acquisition: yes-no- and why-questions. Vykladannia mov $u$ vyshchykh navchalnykh zakladakh osvity na suchasnomu etapi. Mizhpredmetni zviazky [Teaching Languages at Higher Institutions], 34, pp. 246-257 [in English].

Chierchia, G., Crain, S., Guasti, M., Gualmini, A. and Meroni, L. (2000). The acquisition of disjunction: Evidence for a grammatical view of scalar implicatures. Proceedings of the 25th Boston University Conference of Language Development. Somerville, MA: Cascadilla Press, pp. 157-168 [in English].

Crain, S., Gardner, A., Gualmini, A.and Rabbin, B. (2002). Children's command of negation. Yukio Otsu (Ed.). Proceedings of the third Tokyo Conference on Psycholinguistics. Tokyo: Hituzi Publishing Company, pp. 71-95 [in English].

Crain, S., Goro, T. and Thornton, R. (2006). Language Acquisition is Language Change. Journal of Psycholinguistic Research, 35 (1), pp. 3149. DOI: 10.1007/s10936-005-9002-7 [in English].

de Villiers, J. and de Villiers, P. (1978). Language Acquisition. Cambridge, Mass.: Harvard Univ. Press [in English].

Dimroth, Ch. (2010). The acquisition of negation. Horn, L.R. (Ed.). The expression of negation. Berlin: De Gruyter Mouton, pp. 39-73. DOI: 10.1515/9783110219302.39 [in English].

Erreich, A., Valian, V. and Winzemer, J. (1980). Aspects of a theory of language acquisition. Journal of Child Language, 2, pp. 157-179 [in English].

Goro, T. and Akiba, S. (2004). The acquisition of disjunction and positive polarity in Japanese. Garding, G. and Tsujimura, M. (Eds.). Proceedings of WCCFL 23. Somerville, MA: Cascadilla Press, pp. 101-114 [in English]. 
Gualmini, A., Crain, S. and Meroni, L. (2000). Acquisition of disjunction in conditional sentences. Proceedings of the 24th Boston University Conference of Language Development. Somerville, MA: Cascadilla Press, pp. 367-378 [in English].

Ingram, D. (1992). First Language Acquisition. Cambridge: Cambridge Univ. Press [in English].

Islam, Y. (2015). Phases in L1 Acquisition of Negation: A Comparative Study of Cairene Arabic and English. SKASE Journal of Theoretical Linguistics, 12 (4), pp. 17-27 [in English].

Kusmanto, J., and Pulungan, A. (2003). The acquisition of English negation "no" and "not": evidences from an Indonesian child in non-native parents bilingual program. K@ta: a Biannual Publication on the Study of Language and Literature, 5 (1), pp. 41-48 [in English].

Notley, A., Zhou P., Jensen B. and Crain, S. (2012). Children's interpretation of disjunction in the scope of "before": A comparison of English and Mandarin. Journal of Child Language, 39 (3), pp. 482-522 [in English].

Tieu, L., Yatsushiro, K., Cremers, A., Romoli, J., Sauerland, U. and Chemla, E. (2017). On the Role of Alternatives in the Acquisition of Simple and Complex Disjunctions in French and Japanese. Journal of Semantics, 34 (1), pp. 127-152. Available at: https://doi.org/10.1093/jos/ffw010 [in English].

Стаття надійшла до редакиії: 17.09.2019

Черноватий Леонід Миколайович, докт. пед. наук, проф. кафедри перекладознавства імені Миколи Лукаша факультету іноземних мов Харківського національного університету імені В.Н. Каразіна (61022, Харків, майдан Свободи, 4); e-mail: leonid.chernovaty@karazin.ua; orcid: http://orcid.org/0000-0003-3411-9408.

Черноватый Леонид Николаевич, докт. пед. наук, проф. кафедры переводоведения имени Николая Лукаша факультета иностранных языков Харьковского национального университета имени В.Н. Каразина (61022, Харьков, площадь Свободы, 4); e-mail: leonid.chernovaty@karazin.ua; orcid: http://orcid.org/0000-0003-3411-9408. Leonid Chernovaty, Doctor of Pedagogics, Professor, The School of Foreign Languages, The Department of English Translation Theory and Practice, V.N. Karazin Kharkiv National University (61022, Kharkiv, 4 Svoboda Square); e-mail: leonid.chernovaty@karazin.ua; orcid: http://orcid.org/00000003-3411-9408. 